\title{
SOCIAL MEDIA AND SOCIAL ENTREPRENEURSHIP: TWO BROTHERS ON SAME MISSION
}

\author{
Nadeem Ahmed \\ Department of Media \& Communication Studies, Shaheed Benazir Bhutto University, \\ Shaheed Benazirabad, Pakistan \\ Maria Issani \\ Department of Media \& Communication Studies, Shah Abdul Latif University, \\ Khairpur, Pakistan \\ Shoukat Ali Mahar \\ Department of Public Administration, Shah Abdul Latif University, Khairpur, Pakistan
}

\section{Dr. Ahmed Raza ul Mustafa}

Department of Economics, Shaheed Benazir Bhutto University,

Shaheed Benazirabad, Pakistan

\section{Shumaila}

Department of Management Sciences, University of Wuhan, China

\begin{abstract}
Day by day world goes to adopt new trends in business and all businesses are frequently moving to capture targeted customers and earn maximum benefit. However, entrepreneurship is way to start business without any high investment unquestionably it is a business where ideas are more important than investment on other side social media is convenient way of communication and to render message to masses in this regard association between en trepreneurship and social media is seen. Where it is measured that people are eager to start their own business through social media even in Pakistan but unluckily, they did not possess maximum skills to use social media as a source of business whereas, entrepreneurship is also new idea for them. F or this sample is taken university students of Khairpur district and reliability is checked through Cronbach alpha and EFA exploratory factor analysis is used regression and Pearson correlation is also used. in this way entire acquired data is executed in SPSS version .25 and quantitative research is carried out to see multiple dimensions of social media and entrepreneurship. It is learnt that social media is directly used as the best provision to advertise and market the set intention. It can allow us to use all
\end{abstract}


images, videos, arguments and other activities as the resources of entrepreneurship or business if one deserves to commercialized it.

Key words: Social Media, Entrepreneurship, Business and Marketing

Cite this Article: Nadeem Ahmed Diou, Maria Issani, Shoukat Ali Mahar, Dr. Ahmed Raza ul Mustafa, and Shumaila, International Journal of Management, 11(11), 2020, pp 2090-2097.

http://iaeme.com/Home/issue/IJM?Volume=11\&Issue $=12$

\section{INTRODUCTION}

Social media is not a new concept. It is started and evolving since the human interaction has started.(Simeon Edosomwan, 2011) In $21^{\text {st }}$ century social media is not remained only source of transforming information or just only communication but more than communication social media is useful for changing business behavior in both aspect seller and buyer as well. In this decade social media have great importance and its role is very important to share business information (Simeon Edosomwan, 2011). Nowadays it is observed that masses especially youth, and teenagers using social media continuously many hours, they liked and subscribed many online shopping pages and channels respectively. People are get information about different products on social networking sites because online links are available on social websites to get information and product on reasonable prices. In this age if social media we believe that social media have played vital role to grow business. From year of 2000 to many social networking sites launch their position in different area of interest like music, education, information and business also. These sites with entertainment also promote advertisement and affected business in positive manners and give valuable promotion to various products. (Simeon Edosomwan, 2011). Social Media get rapid growth in current time.

\section{USE OF SOCIAL MEDIA FOR BUSINESSES}

Now day's social media is mostly used for communication with customers. Because social media especially Whatsapp, Facebook is best platform to communicate customers toward new offers, and news products also. Because familiar e-commerce application failed to communicate firms, brands message to their customers or target users. (Mary J. Culnan, 2010) Basically social media rapidly and strongly changing the way we communicate, recently in this era information technology impact on business highly observe within and outside of boundaries. Social media and business relation is also highly observed and appreciated. (Sinan Aral, anuary 14, 2013) Because of social media used and its popularity now social media raised its position as a best marketing weapon for not only business firms but also for the individuals. The used of social media in marketing and business promotion is not a new idea. In many developed countries from last many years to Social Media is using as a marketing tool but it's also a bitter truth that importance of social media in Entrepreneurship still remain out of research.

Objective 1: To determine the association between social media and entrepreneurship users in Khairpur

Question 1: Is there any association between social media and entrepreneurship users in Khairpur

Objective 2: To find out contribution of social media in predicting entrepreneurship among users of Khairpur

Question 2: How much contribution of social media in predicting entrepreneurship among users of Khairpur 
Objective 3: To determine the if there is negative association between social media and entrepreneurship users in Khairpur

Question 3: Is there any negative association between social media and entrepreneurship users in Khairpur

\section{LITERATURE REVIEW}

Social media is great source of attraction for masses. in this era people change their idea towards online shopping and before online shopping and purchasing any new product people always ask their friends and peer for reliability of products and brand even some opinion followers type people before purchasing check social media to known product rating because adds displayed on social media help them to understand product rating and reliability (Woodcock, 2010). After this study it is easy to establish this hypothesis that,

H11: There is significant association between social media and entrepreneurship

In online business the importance of social media can't be denied on any coast because in direct marketing to provide motivation to buyers and interested customers is a very difficult task for managers, Market and sales represented and also difficult to control some content of information but on social media information of products and motivation to purchase product is much easy way because its seen many time the through short videos, jokes, entertainment messages, sharing of experiences and social media post brands and products owner shared message without any hurdle also buyers take notice of shared post of already users based on their experience. Simply social media is a best forum to form opinion for opinion followers. Nowadays online marketing rapidly taken growth and attention of buyers. Social media positively can have used as a tool of marketing for business organization of various size and types and importance of social media in performance of organization and marketing is remarkable in this decade (Birkner, 2011). Not only for large business organization even for small enterprises the social media is a good tool to communicate their customers on lower coast on short time with best manners and with higher efficiency also this way is out of tradition that's way people like it more than other way of publicity and advertising (Kaplan, 2010).

\section{ENTREPRENEURSHIP IS CREATIVE IDEA FOR BUSINESS WITHOUT MUCH INVESTMENT}

Mostly people especially youth avoid to start any new business or firm because they think that for the start of new business a huge amount of finance, skills, and expertise are required. It is a view make disappointed to start new business. Many people of our nation are interested in job because they don't want to take risk of loss money. No doubt that in starting of a major business or for social development and for self-improvements or stability, large factories, precious machines and large services and huge amount and investment are required, but these all sources are not obligatory or compulsory. Many opportunities are available which can have started without all mentioned resources and huge investment. Many businesses can have started without huge amount and developed without the many skills just is need to introduce new ideas in business which called entrepreneurship. Link Between Social Media and Entrepreneurship.

Use of social is a new idea in business field. The basic theme and idea of social media is to keep connected yourself with others further sharing of ides through social media posts, entertainment, and engaging the time further now social media is developed in use of entrepreneurship. Now days creativity idea of social media made its wonderful idea because social media is best plate form to communicate and keep connected with others, and online networking and social networking sites can easily provide publicity and business growth 
(Ojeleye, 2018) But in discussion of this study it is clearly mentioned that basically social media is a platform for the Social activity so it can say that,

\section{H10: There is no significant association between social media and entrepreneurship.}

basically the entrepreneur is a one who ready for business, recognize business opportunity and accept risk of assets lose (Ojeleye, 2018). An Entrepreneur is a one individual, as initiator or driver who one is make something new and can be apply either in activity business, organization and so on (Torre, 2015).

\section{H3: There is negative association between social media and entrepreneurship.}

Another words we can say that Entrepreneurship is a process to introduce new ideas in in the field of business regardless the resources (Timmons, 1994) and social media can help to establish new business because it is a bitter truth that without advertising or proper publicity establishment of new business I one of the difficult task but it's make easy SNS. Now days through SNS publicity is very simple task people through social networking posts share their new ideas, shops name characteristics, and available services on lowest coast or whatever they are providing, online shopping is also on same cue. Social media is a new concept or it is convergence of media because Social media is converging, improving and developed way of new media. Social media is a great source of improve and develop entrepreneurial goals (Mah, 2010). Hoag and Seo define media entrepreneurship as the creation and ownership of a small enterprise or organization whose activity adds at least one voice or innovation to the media marketplace.(3).

Here a question may raise that how social media is playing its role in entrepreneurship? The answer of said question is that Social Media allows to access businesses to those resources which is no available them easily likewise its easy way to communicate customers, way to increase supplier contacts, development of organization worthiness and put torch on areas where finance is available. Not only the mentioned resources also encourage innovation, modernization and provide assistance in the cultivation of strategic premeditated businesses and partnership. Owing to of the elasticity of SNS tools, different benefits in promotion of businesses is observing and different benefits cannot ignore. Social media proved that it is a milestone in the world of advanced entrepreneurship because social media improved customer relation, idea for product selection and many other benefits. Social media can build log time relationship among customers, organization, and businesses.

\section{SOCIAL MEDIA CLEARS WAY FOR ENTREPRENEURSHIP}

Many business organizations are using social media as a tool of business promotion nowadays. For effective promotion online presence is very important. The way of advertising is growing change rapidly and need to understand businesses owners to this change of developed technologies and role of SNS. In today's world social media application most popular and powerful tool for small business growth, small business organizations establish their fan pages, brand introduction and publicity/ promotion pages where they welcome comments for improving product quality for improving the business in real and introduce new products to their customers and not only large firms social media is even very popular, and useful to small entrepreneur (Shabbir, 2016). (Geho, 2012) Mentioned in his research with the reference of reports that "60 percent of people who use three or more digital means of research for product purchases learned about a specific brand or retailer from a social networking site". 


\section{ARE PEOPLE USE SOCIAL MEDIA AS AN ENTREPRENEURIAL ACTIVITY?}

The Small and Medium enterprises (SMEs) are very interesting in aspect of social networking, not only interested but also worth exploring at same time, because social media channels, applications and sites are providing simple, easy and lowest coast advertising and publicity and considering affordable marketing tool (Dutta, 2010). The $21^{\text {st }}$ century is a centenary of social media revolution. In 2004 (Smith, 2004) Disclose in his research that now days companies, firms and business organization using new technologies or we can say that feeling several new surprising events foor promotion of business and internet channel as a source of communication is one of the most powerful feature. Internet introduce several new elements and because of these new elements consumers and product users are more reachable to information of products, brand and services provided by the small, medium and large enterprises. Through internet communication is very easier and earlier means we can say that internet is emerging communication tool in entrepreneurship for exchanging information about product and through it companies communicate their users and customers easier and fasters (Jagongo, 2013) after this detail discussion and opinion of previous researcher we are able to mentioned that people are using social media and internet as an entrepreneurial activity, and this activity is very beneficial for both business owners and at same time for customers to get knowledge and information about products.

\section{RESEARCH METHODOLOGY}

This is important for the researcher that $\mathrm{S} /$ he should describe his research title through the already published research and objective, problem statement, and hypothesis respectively Because researchers believes that process of research methodology explain work, in which researcher comprises methods in a way to forecast research problems and also explain the phenomena and in other words research methodology is a plat to how knowledge is attained. The philosophy of this academic research is Positivism for the data collection strategy of Survey method is being used and questioner is used as the tool and it was self- designed and based on 5-point Likert Scale. This study is basically quantitative research and time horizon is cross sectional. Targeted population of this study is Students of Shah Abdul Latif University Situated in Khairpur city of Sindh Pakistan. This University offered education in Seven Faculties. The students of Shah Abdul Latif University Khairpur were targeted population because divers groups of the youngsters both Male \& female arrive here across the Sindh. So a number of respondents are available in university from different Districts of Sindh. Though Shah Abdul Latif University Khairpur is selected as a targeted population because young students of different districts of Sindh are enrolled here.

Table 1 DESCRIPTIVE STATISTICS

\begin{tabular}{|c|c|c|c|c|}
\hline NAME & OPTION & NUMBER & PERCENTAGE & TOTAL \\
\hline \multirow{5}{*}{ Age } & 18 to 20 & 75 & 47.5 & \multirow{5}{*}{100} \\
\hline & 21 to 23 & 59 & 37.3 & \\
\hline & 24 to 26 & 20 & 12.7 & \\
\hline & 27 to 29 & 3 & 1.9 & \\
\hline & Above 30 & 1 & .6 & \\
\hline \multirow{2}{*}{ Gender } & Male & 99 & 62.7 & \multirow{2}{*}{100} \\
\hline & Female & 59 & 37.3 & \\
\hline Location & Rural & 112 & 70.9 & 100 \\
\hline
\end{tabular}




\begin{tabular}{|c|c|c|c|c|}
\hline & Urban & 46 & 29.1 & \\
\hline \multirow{2}{*}{ Do you use Social Media? } & yes & 142 & 89.9 & \multirow{2}{*}{100} \\
\hline & no & 16 & 10.1 & \\
\hline \multirow{5}{*}{$\begin{array}{l}\text { What are the application that you } \\
\text { use frequently }\end{array}$} & Facebook & 35 & 22.2 & \multirow{5}{*}{100} \\
\hline & YouTube & 50 & 31.6 & \\
\hline & WhatsApp & 23 & 14.6 & \\
\hline & twitter & 21 & 13.3 & \\
\hline & $\begin{array}{l}\text { Facebook and } \\
\text { YouTube }\end{array}$ & 29 & 18.4 & \\
\hline \multirow{2}{*}{$\begin{array}{l}\text { Do you use social media for } \\
\text { commercial purpose? }\end{array}$} & yes & 45 & 28.5 & \multirow{2}{*}{100} \\
\hline & no & 113 & 71.5 & \\
\hline \multirow{2}{*}{ Are you an Entrepreneur? } & yes & 38 & 24.1 & \multirow{2}{*}{100} \\
\hline & no & 120 & 75.9 & \\
\hline $\begin{array}{l}\text { Does Social Media benefit } \\
\text { entrepreneurship }\end{array}$ & yes & 135 & 85.4 & 100 \\
\hline
\end{tabular}

It is chart of descriptive statistics, in which demographic details of respondent is mentioned. In research methodology it is already explain that questioner is based on 5-point Likert Scale.

Table 2

Reliability Statistics

\section{Reliability Statistics}

In Research, the technique of_Cronbach's Alpha is used to measure the reliability of questionnaire so this technique is used to check the reliability of data which is mentioned in questionnaire. As per the standards rules of Cronbach's Alpha if findings are below the 0.6 it will consider poor whereas 7 and above is weak and 0.8 and above is consider strong. For data collection questioner is used as a tool and it was consisted of 25 Questions. Reliability 0.889 $\%$ which is strong as above mentioned. 
Table 3

\begin{tabular}{|c|c|c|c|c|}
\hline \multicolumn{5}{|c|}{ Model Summary } \\
\hline Model & $\mathrm{R}$ & R Square & Adjusted R Square & $\begin{array}{l}\text { Std. Error of the } \\
\text { Estimate }\end{array}$ \\
\hline 1 & $.462^{n}$ & .214 & .209 & .88950600 \\
\hline
\end{tabular}

\begin{tabular}{|c|c|c|c|c|c|c|}
\hline \multicolumn{7}{|c|}{ ANOVA $^{a}$} \\
\hline Model & & Sum of Squarea & df & Mean Square & $\mathrm{F}$ & Sig. \\
\hline \multirow[t]{3}{*}{1} & Regreasion & 33.570 & 1 & 33.570 & 42.428 & $.000^{\mathrm{b}}$ \\
\hline & Reaidual & 123.430 & 156 & .791 & & \\
\hline & Total & 157.000 & 157 & & & \\
\hline
\end{tabular}

๑. Dependent Variable: ENTERPRENURSHIP

b. Predictora: (Conatant), SOCIAL MEDIA

\begin{tabular}{|c|c|c|c|c|c|c|}
\hline \multicolumn{7}{|c|}{ Coefficients ${ }^{\mathrm{a}}$} \\
\hline \multirow[b]{2}{*}{ Model } & & \multicolumn{2}{|c|}{ Unatandardized Coefficienta } & \multirow{2}{*}{$\begin{array}{c}\text { Standardized } \\
\text { Coefficients } \\
\text { Beta } \\
\end{array}$} & \multirow[b]{2}{*}{$t$} & \multirow[b]{2}{*}{ Sig. } \\
\hline & & $\mathrm{B}$ & Std. Error & & & \\
\hline \multirow[t]{2}{*}{1} & (Constant) & $3.122 \mathrm{E}-17$ & .071 & & .000 & 1.000 \\
\hline & SOCIAL MEDIA & .462 & .071 & .462 & 6.514 & .000 \\
\hline
\end{tabular}

a. Dependent Variable: ENTERPRENURSHIP

shows that reliability measured 0.804 .

is statically approach to measure the essence of dependent variable and independent variables, so it has been shown in table of ANOVA independent variable predicts dependent variable, when significant result is 0.000 .

\section{CONCLUSION}

The main purpose of this study was the elaborate the social media association with entrepreneurs for business purposes in an emerging market and many previous researches indicated that internet and social media usage have been growing significantly in emerging markets. It is a universal truth and real fact that change is always remained a permanent feature of the Nature. Keeping in view this statement human beaning adopting new trends in all fields of the life and business in one of them. Every day new research and practices taken place in business field for attraction of target customers and for earning maximum benefits business community is adopting new trends to improve business. In this regard entrepreneurship is one of the important idea to improve and start new business without any high investment unquestionably it is a business where ideas are more important than investment on other side social media is convenient way of communication and to render message to masses in this regard association between entrepreneurship and social media is seen. Where it is measured that people are eager to start their own business through social media even in Pakistan but unluckily, they did not possess maximum skills to use social 
media as a source of business whereas, entrepreneurship is also new idea for them. Social Media used in starting and promotion of many businesses highly encouraged in recent past because It is learnt that social media is directly used as the best provision to advertise and market the set intention. It can allow us to use all images, videos, arguments and other activities as the resources of entrepreneurship or business if one deserves to commercialized it. No doubt that online Social Media offered number of opportunities to improve and increase competitive global business and environments of businesses and even more Social Media Users used Social Media for startups new business with limited marketing budgets.

\section{REFERENCES}

[1] Birkner, C. (2011). Sharing the Love. . Marketing News,45(3), 11-12.

[2] Dutta, S. (2010). What's your personal social media strategy?', . Harvard Business Review, Vol. 88, 127-130.

[3] Geho, P. R. (2012). The Evolution Of Social Media As A Marketing Tool For Entrepreneurs. Entrepreneurial Executive, 61.

[4] Jagongo, A. (2013). The Social Media and Entrepreneurship Growth (A New Business Communication Paradigm among SMEs in Nairobi). International Journal of Humanities and Social Science, 213-227.

[5] Kaplan, A. M. (2010). Users of the world, unite! The challenges and lucre of social media. Business Horizons, 53 (1), 59-68. Business Horizons, 59-68.

[6] Mah, J. Z. (2010). Social Networking a Source for Developing Entrepreneurial Intentions Among Entrepreneurs: A Case of Multan. Asian Economic and Financial Review 2(8),, 102108.

[7] Mary J. Culnan, P. J. (2010). How Large U.S. Companies Can Use Twitter and Other Social Media to Gain Business Value. MIS Quarterly Executive, 243-259.

[8] Ojeleye, Y. C. (2018). Impact Of Social Media On Entrepreneurship Development Among Users In Zamfara State. Journal of Economics \& Finance.

[9] Shabbir, M. S. (2016). Impact of Social Media Applications on Small Business Entrepreneurs. Arabian Journal of Business and ar And Management Review.

[10] Simeon Edosomwan, S. K. (2011). The history of social media and its impact on business. Journal of Applied Management \& Entrepreneurship Vol. 16, No.3 .

[11] Sinan Aral, C. D. (anuary 14, 2013). Introduction to the Special Issue-Social Media and Business Transformation: A Framework for Research. Information Systems Research.

[12] Smith, P. a. (2004). Marketing Communications: An Integrated Approach. . . London: Kogan Page Limited.

[13] Timmons, J. (1994). New Venture Creation: Entrepreneurship for the 21stt Century. Fourth edition. Illinois: Irwin Press, Burr Ridge,.

[14] Torre, J. D. (2015). Who is an Entrepreneur? . https://www.entrepreneur.com/article/245628 Accessed 7 July 2017.

[15] Woodcock, N. \&. (2010). The Customer Framework". Retrieved at http://customerframework.com . Social CRM as a Business Strategy, . 